\title{
Hemoadsorption efficacy for uncomplicated high-risk cardiac surgery
}

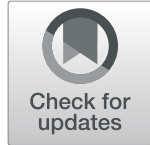

\author{
Sébastien Redant ${ }^{1}$, Matthieu Legrand², Yael Langman ${ }^{1}$, Alejandra Garcia Aguilar ${ }^{3}$, François Angoulvant ${ }^{4}$, \\ Keitiane Kaefer ${ }^{1}$, David De Bels ${ }^{1}$, Rachid Attou' ${ }^{1}$ Kianoush Kashani ${ }^{5}$ and Patrick M. Honore ${ }^{1 *}$
}

This comment refers to the article available at https://doi.org/10.1186/s13054-019-2399-4.

We enthusiastically read the paper by Poli et al. related to the use of CytoSorb $^{\circ}$ in high-risk cardiac surgery. While use of CytoSorb ${ }^{\circ}$ showed no clinical or laboratory benefit, it was not associated with any complications either [1]. We noted the low level of interleukin-6 (IL-6) reported in this study (i.e., median values $<50 \mathrm{pg} / \mathrm{ml}$ and $<200 \mathrm{pg} / \mathrm{ml}$ during and after CBP). This observation may explain why there was no obvious benefit. In the paper by Träger et al., a series of 16 post-cardiac surgery patients with systemic inflammation (SI) characterized by a mixture of cardiogenic shock and distributive shock with acute kidney injury requiring continuous renal replacement therapy were enrolled. The authors observed patients prior to treatment with CytoSorb ${ }^{\circ}$ to have baseline IL- 6 and IL- 8 levels between 500 and $10,000 \mathrm{pg} / \mathrm{mL}$ and 50 and $1000 \mathrm{pg} / \mathrm{mL}$, respectively. Along with a decrease in the interleukin levels, hemodynamic parameters including cardiac index and mean arterial pressure improved and the need for catecholamine declined [2]. The same benefit was observed when CytoSorb ${ }^{\circ}$ was used intraoperatively for patients with endocarditis. These patients had a high level of IL- 6 and IL-8 prior to the intervention [3]. It is also reported that among septic patients with elevated IL-6 $(>1000 \mathrm{pg} / \mathrm{mL})$ requiring continuous renal replacement therapy, cytokine clearance was more efficient when hemoperfusion and hemoadsorption were utilized [4]. Patients with a significant preoperative SI, such as in endocarditis or sepsis or with complicated surgery, are the most likely to benefit from CytoSorb ${ }^{\circ}$ therapy. We agree with the authors that some cardiac surgery patients might benefit from hemoadsorption device, but we believe that the indication should be tested in patients with a high level of circulating cytokines-such as IL-6 [5].

\footnotetext{
* Correspondence: Patrick.Honore@CHU-Brugmann.be

${ }^{1}$ ICU Department, Centre Hospitalier Universitaire Brugmann-Brugmann University Hospital, Place Van Gehuchtenplein,4, 1020 Brussels, Belgium Full list of author information is available at the end of the article
}

Abbreviations

CBP: Cardiopulmonary bypass; IL-6: Interleukin-6; IL-8: Interleukin-8; SI: Systemic inflammation

\section{Acknowledgements \\ None.}

\section{Authors' contributions}

$\mathrm{SR}, \mathrm{KK}$, and PMH designed the paper. All authors participated in drafting and reviewing. All authors read and approved the final version of the manuscript.

\section{Funding}

None.

Availability of data and materials

Not applicable.

Ethics approval and consent to participate

Not applicable.

Consent for publication

Not applicable.

Competing interests

The authors declare that they have no competing interests.

\section{Author details}

${ }^{1}$ ICU Department, Centre Hospitalier Universitaire Brugmann-Brugmann University Hospital, Place Van Gehuchtenplein,4, 1020 Brussels, Belgium. ${ }^{2}$ Department of Anesthesiology, Critical Care and Burn Unit, St. Louis Hospital, University Paris 7 Denis Diderot, UMR-S942, Inserm, Paris, France. ${ }^{3}$ Hospital General de Zona No. 14 IMSS, Universidad Autónoma de Guadalajara, Guadalajara, Mexico. ${ }^{4}$ Service d'accueil des Urgences Pédiatriques, Necker-Enfants Malades University Hospital, Assistance Publique-Hôpitaux de Paris, Paris, France. ${ }^{5}$ Division of Nephrology and Hypertension, Division of Pulmonary and Critical Care Medicine, Mayo Clinic, Rochester, MN, USA.

Received: 14 September 2019 Accepted: 1 October 2019

Published online: 04 November 2019

References

1. Poli EC, Alberio L, Bauer-Doerries A, Marcucci C, Roumy A, Kirsch M, et al. Cytokine clearance with CytoSorb during cardiac surgery: a pilot randomized controlled trial. Crit Care. 2019;23(1):108. https://doi.org/10. 1186/s13054-019-2399-4.

2. Träger K, Fritzler D, Fischer G, Schröder J, Skrabal C, Liebold A, et al. Treatment of post-cardiopulmonary bypass SIRS by hemoadsorption: a case series. Int J Artif Organs. 2016;39(3):141-6. https://doi.org/10.5301/ijao. 5000492. 
3. Träger K, Skrabal C, Fischer G, Datzmann T, Schroeder J, Fritzler D, et al. Hemoadsorption treatment of patients with acute infective endocarditis during surgery with cardiopulmonary bypass - a case series. Int J Artif Organs. 2017;40(5):240-9. https://doi.org/10.5301/ijao.5000583.

4. Schädler D, Pausch C, Heise D, Meier-Hellmann A, Brederlau J, Weiler N, et al. The effect of a novel extracorporeal cytokine hemoadsorption device on IL-6 elimination in septic patients: a randomized controlled trial. PLoS One. 2017;12(10):e0187015. https://doi.org/10.1371/journal.pone.0187015.

5. Honore PM, Hoste E, Molnar Z, Jacobs R, Joannes-Boyau O, Malbrain MLN, Forni L. Cytokine removal in human septic shock: where are we and where are we going? Ann of Intensive Care. 2019;9(1):56. https://doi.org/10.1186/ s13613-019-0530-y

\section{Publisher's Note}

Springer Nature remains neutral with regard to jurisdictional claims in published maps and institutional affiliations. 